\title{
P53/microRNA-34-induced metabolic regulation: new opportunities in anticancer therapy
}

\author{
Ding-Guo Zhang ${ }^{1}$, Jun-Nian Zheng ${ }^{1,2^{*}}$ and Dong-Sheng Pei ${ }^{\text {* }^{*}}$
}

\begin{abstract}
MicroRNA-34 (miR-34) is directly regulated by p53, and its potential tumor suppressive roles have been studied extensively. As a p53-induced microRNA, miR-34 functions as a tumor suppressor by playing a role in cell cycle arrest, apoptosis and metabolic regulation. Among these p53/miR-34 associated processes, apoptosis and cell cycle arrest are known as essential for p53/miR-34-mediated tumor suppression. P53-mediated metabolic processes have been shown to play pivotal roles in cancer cell biology. Recent studies have also identified several miR-34 targets involved in p53/miR-34-induced metabolic regulation. However, correlations among these metabolic targets remain to be fully elucidated. In this review, we summarize the current progress in the field of metabolic regulation by the p53/miR-34 axis and propose future directions for the development of metabolic approaches in anticancer therapy.
\end{abstract}

Keywords: LDHA, Metabolism, miR-34, MYC, p53, SIRT1

\section{Introduction}

MicroRNAs (miRNAs) are small noncoding RNAs that regulate gene expression by binding to complementary sequences in the 3'UTR of mRNAs. The identification of the first miRNA, Lin-4, which was found in worms [1], was followed by an increasing interest in understanding the realm of small noncoding RNAs. Aberrant regulation of miRNAs is found in many types of human cancer [2,3]. A number of studies have shown that miRNAs can regulate apoptosis, cell proliferation and epithelial-mesenchymal transition in cancer cells [4-7]. Here, we focus on the miR-34 family and investigate the therapeutic potential of p53/miR-34-induced metabolic regulation for the treatment of cancer.

The miR-34 family includes miR-34a, miR-34b and miR-34c, which are encoded by two different genes. MiR34a is encoded by its own transcript, while miR-34b and miR-34c share a common primary transcript. Members of the miR-34 family have tissue-specific functions, as miR$34 \mathrm{a}$ is expressed in the brain, whereas miR-34b/c is largely expressed in the lungs $[8,9]$. Studies have shown that aberrant expression of the three miR-34 members exists in many cancers [9-16]. MiR-34 genes that are directly

\footnotetext{
* Correspondence: jnzheng@xzmc.edu.cn; dspei@xzmc.edu.cn
'Jiangsu Key Laboratory of Biological Cancer Therapy, Xuzhou Medical

* Correspondence: jnzheng@xzmc.edu.cn; dspei@xzmc.edu.cn
'Jiangsu Key Laboratory of Biological Cancer Therapy, Xuzhou Medical College, 84 West Huai-hai Road, 221002 Xuzhou, Jiangsu, China ${ }^{2}$ Center of Clinical Oncology, Affiliated Hospital of Xuzhou Medical College, Xuzhou 221002, China
}

regulated by $\mathrm{p} 53$ have been identified $[8,17,18]$, and their involvement in p53-mediated cellular responses associated with tumor suppression such as apoptosis [17,19], cell cycle arrest $[20,21]$ and metabolic regulation [22] has been demonstrated. The promotion of apoptosis along with the induction of cell cycle arrest, which are pivotal for p53mediated tumor suppression, were the first outcomes observed after the ectopic expression of miR-34 [20]. A number of direct miR-34 targets, including B-cell CLL/ lymphoma 2 (Bcl-2), baculoviral IAP repeat containing 5 and silent information regulator 1 (SIRT1), are related to cellular apoptosis [23]. Another class of miR-34 targets including v-myc avian myelocytomatosis viral oncogene homolog (MYC), E2F transcription factor 3 and cyclin E2 are involved in the induction of G1 arrest [10,11,24], and miR-34 targets associated with metabolic regulation governed by p53 have also been identified [22,25]. P53/miR34-mediated apoptosis and cell cycle arrest have been studied extensively, whereas metabolic regulation through the p53/miR-34 axis is not fully understood, in particular the correlations among miR-34-induced metabolic targets. Recently, an increasing number of studies have shown an association between metabolism and p53, which indicates that metabolic regulation may play a critical role in p53induced tumor suppression and suggests that the roles of metabolism and canonical processes of p53 in human cancer need further evaluation [26,27]. In addition, miR-34 
has been implicated in metabolism and metabolic disorders [28-30]. In the present review, we summarize the evidence and research progress in metabolic regulation mediated by p53/miR-34 to shed light on the potential of the p53/miR-34 axis as a therapeutic target for the treatment of cancer.

\section{Tumor suppressive roles of $\mathrm{p} 53$-mediated metabolism}

Studies have shown that the metabolic targets of p53 are associated with glycolysis [31-34], mitochondrial respiration [35] and lipid metabolism [36]. Regarding p53 function, cell cycle arrest and apoptosis have been studied extensively and recognized as essential for p53-induced tumor suppression. However, recent studies found that these canonical processes are not the rate-limiting steps in tumor suppression and suggested metabolic regulation as a crucial step for early-onset spontaneous tumorigenesis $[26,27]$. They generated mice bearing lysine to arginine mutations at one $\left(\mathrm{p} 53^{\mathrm{K} 117 \mathrm{R}}\right)$ or three $\left(\mathrm{p} 53^{3 \mathrm{KR}} ; \mathrm{K} 117 \mathrm{R}+\right.$ $\mathrm{K} 161 \mathrm{R}+\mathrm{K} 162 \mathrm{R}) \mathrm{p} 53$ acetylation sites and found that p53mediated cell cycle arrest and apoptosis were abrogated by the loss of acetylation at all three sites. Interestingly, earlyonset tumor formation did not occur in animals carrying either mutation, suggesting that the combined loss of p53dependent cell cycle arrest, apoptosis and senescence was inadequate to abolish the p53-mediated tumor suppression. The fact that $\mathrm{p} 53^{3 \mathrm{KR}}$ retains the ability to regulate the expression of metabolic p53 target genes, together with data on glucose uptake and glycolysis tests, led the authors to suggest that $\mathrm{p} 53^{3 \mathrm{KR}}$ retains its activity at least partly through the regulation of energy metabolism levels in vivo. Further evidence was provided by additional studies in which they generated mice deficient in the p53 proapoptotic effectors p21, Puma and Noxa [27], the expression of which was only reduced rather than abrogated in the former study. This study also confirmed that instead of cell cycle arrest and apoptosis, metabolic regulation might be critical for p53-mediated tumor suppression. These results provided a new angle to further investigate the mechanism underlying the function of p53 in tumor suppression.

\section{Feedback loops in the p53/microRNA-34 network}

In 2007, miR-34 family members were reported to be direct p53 targets and shown to induce apoptosis and cell cycle arrest $[17,18]$. Further studies indicated that miR-34 functions as a tumor suppressive miRNA and plays a role in the regulation of p53 expression, and in turn p53 directly regulates miR-34 and thereby induces cellular processes associated with tumor suppression. MiR-34 can repress SIRT1 [30], histone deacetylase 1 (HDAC1) [22,37] and the transcriptional factor YY1 $[22,38,39]$, and thereby forms positive feedback loops for p53 activation. An increasing number of miR-34 targets have been identified and many of them are associated with tumor suppression, with most of them governed by p53. P53/miR-34-mediated tumor suppressive processes include apoptosis and cell cycle arrest, stemness, metastasis and metabolism [40-43]. Among these cellular responses, apoptosis and G1 arrest were the first processes associated with ectopic expression of miR-34 and have been studied extensively. However, other p53/miR-34-induced processes such as metabolic regulation remain to be fully elucidated.

\section{Collaboration of p53/microRNA-34 targets in metabolic regulation}

Several miR-34 targets are associated with metabolic processes, among which lactate dehydrogenase A (LDHA), MYC and SIRT1 are of central importance [10,22,25,44]. These three direct miR-34 targets have tight connections with one another and function collaboratively in p53/miR34-mediated metabolic regulation.

Numerous tumor suppressors and oncogenes are closely associated in metabolic pathways, and the first documented mechanism involving an activated oncogene in altered glucose metabolism was the transcriptional activation of LDHA by the oncogenic transcription factor MYC [45]. LDHA catalyzes the conversion of pyruvate to lactate and is considered to play a key role in anaerobic glycolysis [46]. The level of LDHA is elevated in many human cancers in correlation with tumor proliferation and malignant growth $[47,48]$. MYC is frequently altered in human cancer and has been reported to regulate many glucose metabolism genes, such as glucose transporter GLUT1 and hexokinase 2 (HK2) [49]. The regulation of cell size, proliferation and cellular metabolism by MYC was proposed to occur in a miR-34-dependent manner $[10,49,50]$. MYC was shown to transactivate the LDHA promoter and directly increase LDHA expression, which suggested that LDHA is a direct target of MYC. Furthermore, the elevated expression of LDHA may be necessary for MYCmediated transformation [45]. LDHA was also shown to be a common target of MYC and the hypoxia inducible factors (HIFs) [51]. HIFs, as well as MYC, are pivotal factors for tumorigenesis in many types of human cancers and are able to activate LDHA [52,53]. The ectopic expression of MYC promotes its collaboration with HIF to confer metabolic advantages to tumor cells, which partly contributes to the Warburg effect $[51,54]$. In this process, the expression of LDHA is activated by both MYC and HIFs. Further studies showed that alterations of LDHA expression lead to changes in cancer metabolism [47,55-57].

Another miR-34 target, SIRT1, also plays a critical role in p53/miR-34-induced metabolism. SIRT1 is a multifaceted $\mathrm{NAD}^{+}$-dependent protein deacetylase that deacetylates 
p53, resulting in the inhibition of its activity [58]. MiR-34 inhibits SIRT1 expression, resulting in a reduction of p53 deacetylation [25]. Thus, SIRT1, p53 and miR-34 form a positive feedback loop to induce tumor suppression. Additionally, SIRT1 can inhibit the miR-34 promoter through histone deacetylation [59].

Close associations between SIRT1 and LDHA have been described, and SIRT1 activity is largely determined by LDHA. SIRT1 is a $\mathrm{NAD}^{+}$-dependent protein deacetylase. $\mathrm{NAD}^{+}$is regenerated from NADH through the reduction of pyruvate to lactate. LDHA plays an essential part in the metabolism of pyruvate and NADH, and thus sustains cellular $\mathrm{NAD}^{+}$levels $[47,60,61]$. Therefore, SIRT1 is under strict control of another miR-34 target, LDHA. Moreover, studies investigating the effect of SIRT1 on LDHA found that depletion of SIRT1 resulted in reduced transcription of LDHA [62].

The correlation between SIRT1 and MYC has also been investigated. A recent study identified a positive feedback loop consisting of MYC, the nicotinamidephosphoribosyltransferase (NAMPT) enzyme, the SIRT1 inhibitor deleted in breast cancer 1 (DBC1) and SIRT1 [63]. This study showed that MYC activates SIRT1, which in return promotes MYC function. MYC induces SIRT1 deacetylase activity and the MYC-induced NAMPT mediates the activity of SIRT1, since the NAD+/NADH ratio is crucial for SIRT1. Moreover, MYC may also activate SIRT1 by directly binding to the SIRT1 inhibitor DBC1. Two separate mechanisms contributing to the MYC-induced SIRT1 activation were identified: 1 . MYC induces NAMPT, resulting in an increase in the SIRT1 cofactor NAD+. 2. The MYC-DBC1 association facilitates SIRT1 activation. Reciprocally, these authors found that SIRT1-mediated deacetylation increases the half-life of MYC, and SIRT1 increases MYC transcriptional activity. Although certain molecular details remain unclear, such as the mechanisms of SIRT1 stabilization and DBC1-SIRT1 interplay, these data highlighted the clinical potential of targeting this feedback loop. Another study showed the positive effect of SIRT1 on MYC by demonstrating that the SIRT1-mediated deacetylation of MYC could promote the association with its essential partner MYC associated factor X, thereby promoting the transcriptional activity of MYC [62].

A possible positive feedback loop consisting of LDHA, MYC and SIRT1 may function collaboratively to regulate cellular metabolism via the p53/miR-34 axis. LDHA, MYC and SIRT1 are direct miR-34 targets and are involved in the p53-mediated metabolic regulation. Rather than functioning independently as miR-34 targets, SIRT1, MYC and LDHA work cooperatively in p53/miR-34-mediated metabolic regulation, thereby acting in a collaborative form instead of in parallel.

Several other p53-induced miRNAs, such as let-7, miR107 and miR-200, may function as direct and indirect regulators of LDHA, MYC and SIRT1 and may broaden our view of the collaborations between miR-34 and other p53-induced miRNAs in metabolic regulation.

The Let-7 miRNA family is one of the most conserved and ancient miRNAs and was found to be regulated by p53 $[64,65]$. The Lin28/let-7 axis regulates glucose metabolism and the RNA-binding protein Lin28 can promote malignancy through the selective inhibition of let-7 biogenesis $[66,67]$. MYC binds to the Lin28 promoter and regulates its expression. Studies have found that Lin28b plays an essential role in MYC-induced let-7 repression and the MYC/let-7/Lin28 pathway is pivotal for cellular transformation [66]. Although further research is needed, it is possible that the let-7-MYC/Lin28 axis plays important roles in glycolytic regulation and this could subsequently contribute to a more complex network involved in $\mathrm{p} 53 / \mathrm{miR}-34$-mediated metabolic regulation. MiR-107 is regulated by p53 and is encoded within an intron of the p53-induced pantothenate kinase 1 gene, PANK1 [68]. Studies have found that p53-induced miR107 can decrease HIF-1 $\beta$ expression, thereby suppressing the transcriptional response to hypoxia and inhibiting tumor angiogenesis [69]. HIF-1 $\beta$ is a subunit of HIF- 1 that can modulate hypoxic responses without affecting HIF- $1 \alpha$ [69]. Since HIF-1 is a regulator of the miR-34 target LDHA, p53-induced miR-107 activation may suppress LDHA expression and lead to the suppression of glycolysis. In addition to LDHA and MYC, p53/miR-107-induced HIF-1 suppression is related to another miR-34 target, SIRT1. SIRT1 negatively regulates HIF-1 through direct deacetylation, and conversely, HIF-1 promotes SIRT1 transcription [70,71]. Thus, the miR-107 target HIF-1 has tight connections with LDHA, SIRT1 and MYC. Moreover, miR-200 was also reported to regulate SIRT1 expression [72]. In summary, the collaborations among LDHA, MYC and SIRT1 can indeed widen the window of miR34-induced tumor suppression (Figure 1).

\section{Therapeutic potential of p53/miR-34-induced metabolic targets}

Since p53 is mutated in approximately $50 \%$ of human cancers and miR-34 is a critical component of p53 signaling pathways, the p53/miR-34-induced metabolic targets may have therapeutic potential. LDHA is a common target of MYC and HIF, both of which work collaboratively in the Warburg effect and are crucial for cellular metabolism. Moreover, NADH-dependent LDHA regenerates NAD + and competes with the mitochondrial NADH/NAD + shuttle system, which is decisive for mitochondrial activity associated with tumor metabolism [73]. Inhibition of LDHA can limit the energy supply and consequently suppress the metastatic and invasive potentials of tumor cells $[46,74]$. This has increased interest in the therapeutic potential of LDHA as a novel target for tumor suppression. 


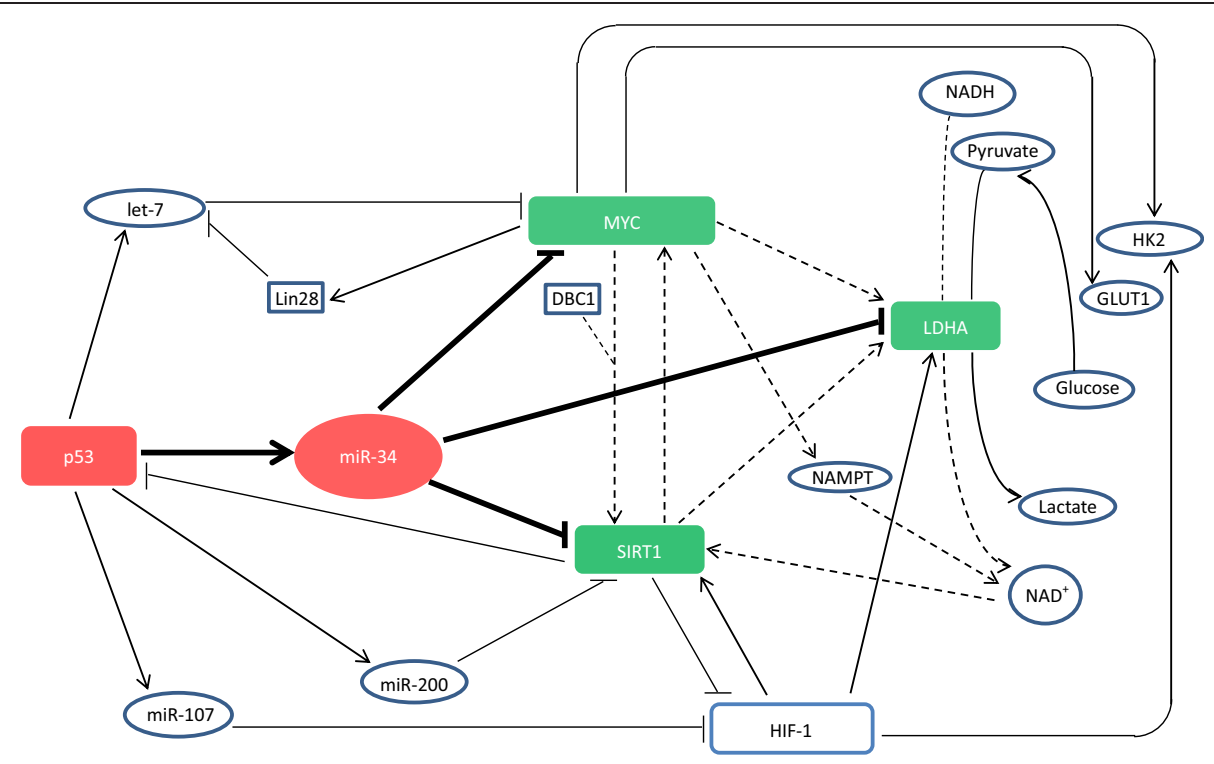

Figure 1 Metabolic regulation by the p53/miR-34 axis and contribution of other related p53-induced miRNAs to the regulatory network. The involvement of LDHA, MYC and SIRT1 in the metabolic regulatory network is illustrated (dotted lines), and the importance of their interaction for miR-34-induced metabolic activity governed by p53 is suggested in the diagram.

Studies have found that total deficiency of LDHA is not associated with any specific symptoms under normal conditions, which indicates that inhibition of LDHA activity could be a nontoxic therapeutic approach to induce tumor suppression [48]. Furthermore, a number of studies have shown that LDHA levels are associated with tumor sensitivity and resistance to therapeutic agents $[46,74,75]$. LDHA has also been suggested as a potential target for chemotherapies. SIRT1 and MYC are also associated with cellular apoptosis and cell cycle arrest through the p53/ miR-34 axis $[10,25]$. The development of small-molecule inhibitors of SIRT1 for the treatment of cancer is under consideration, and activation of SIRT1 alone was suggested as sufficient to induce tumor suppression in human cancers with mutated p53 [76-78]. Moreover, increased levels of MYC are detected in a large number of human cancers. After the first established link between MYC and LDHA, many other glucose metabolism genes have been shown to be governed by MYC, such as glucose transporter 1 and hexokinase $2[79,80]$. Therefore, understanding the therapeutic effects of targeting multiple MYC-mediated metabolic pathways may be crucial for the treatment of cancer.

Several as yet unidentified mechanisms may play a role in the loop consisting of SIRT1, LDHA and MYC, and they should be considered when it comes to therapeutic use. For instance, how MYC overexpression works to regulate both apoptosis and cellular metabolic state remains an unanswered question [51]. Moreover, the potential clinical use of SIRT1 can be complicated:
SIRT1 overexpression is oncogenic in wild-type p53, whereas it plays a tumor-suppressive role in cells with mutated p53. Although this phenomenon has been proposed to be related to p53 status [78], its underlying mechanism requires further clarification. In addition, the exact mechanism of how SIRT1 induces metabolic regulation remains unknown. These uncertainties in the roles of miR-34-induced metabolic regulation need to be clarified.

\section{Conclusions}

In this review, we described the functions of three direct miR-34 targets and their collaboration in regulating metabolism via the p53/miR-34 axis, as well as additional p53-induced miRNAs with the same metabolic targets as miR-34. Additionally, we discussed the significance of these miR-34-induced metabolic targets for anticancer therapies. In summary, metabolic regulation via the p53/ miR-34 axis may be crucial for tumor suppression and therefore, the development of small-molecule drugs targeting LDHA, SIRT1 and MYC may be a novel strategy for anticancer therapy.

\section{Abbreviations}

miRNA: microRNA; miR-34: microRNA-34; miR-107: microRNA-107; miR-200: microRNA-200; HIF-1: Hypoxia inducible factor-1; LDHA: Lactate dehydrogenase A; SIRT1: Sirtuin 1.

\section{Competing interests}

The authors declare that they have no competing interests. 


\section{Authors' contributions}

DGZ collected and read the related paper and drafted the manuscript. DSP and JNZ participated in the design of the review and helped to draft the manuscript. All authors read and approved the final manuscript.

\section{Acknowledgements}

This work was supported by the National Natural Science Foundation of China (No. 81372172) and the key project of the Education Department of China (212062).

Received: 10 February 2014 Accepted: 8 May 2014

Published: 21 May 2014

\section{References}

1. Lee RC, Feinbaum RL, Ambros V: The C. elegans heterochronic gene lin-4 encodes small RNAs with antisense complementarity to lin-14. Cell 1993, 75:843-854.

2. Lu J, Getz G, Miska EA, Alvarez-Saavedra E, Lamb J, Peck D, Sweet-Cordero A, Ebert BL, Mak RH, Ferrando AA, Downing JR, Jacks T, Horvitz HR, Golub TR: MicroRNA expression profiles classify human cancers. Nature 2005, 435:834-838.

3. Volinia S, Calin GA, Liu CG, Ambs S, Cimmino A, Petrocca F, Visone R, lorio M, Roldo C, Ferracin M, Prueitt RL, Yanaihara N, Lanza G, Scarpa A, Vecchione A, Negrini M, Harris CC, Croce CM: A microRNA expression signature of human solid tumors defines cancer gene targets. Proc Natl Acad Sci U S A 2006, 103:2257-2261.

4. Cimmino A, Calin GA, Fabbri M, lorio MV, Ferracin M, Shimizu M, Wojcik SE, Ageilan RI, Zupo S, Dono M, Rassenti L, Alder H, Volinia S, Liu CG, Kipps TJ, Negrini M, Croce CM: miR-15 and miR-16 induce apoptosis by targeting BCL2. Proc Natl Acad Sci U S A 2005, 102:13944-13949.

5. Si ML, Zhu S, Wu H, Lu Z, Wu F, Mo YY: miR-21-mediated tumor growth. Oncogene 2007, 26:2799-2803.

6. Gregory PA, Bert AG, Paterson EL, Barry SC, Tsykin A, Farshid G, Vadas MA, Khew-Goodall Y, Goodall GJ: The miR-200 family and miR-205 regulate epithelial to mesenchymal transition by targeting ZEB1 and SIP1. Nat Cell Biol 2008, 10:593-601.

7. Kim NH, Cha YH, Kang SE, Lee Y, Lee I, Cha SY, Ryu JK, Na JM, Park C, Yoon HG, Park GJ, Yook Jl, Kim HS: p53 regulates nuclear GSK-3 levels through miR-34-mediated Axin2 suppression in colorectal cancer cells. Cell Cycle 2013, 12:1578-1587.

8. Bommer GT, Gerin I, Feng Y, Kaczorowski AJ, Kuick R, Love RE, Zhai Y, Giordano TJ, Qin ZS, Moore BB, MacDougald OA, Cho KR, Fearon ER: p53-mediated activation of miRNA34 candidate tumor-suppressor genes. Curr Biol 2007, 17:1298-1307.

9. Lodygin D, Tarasov V, Epanchintsev A, Berking C, Knyazeva T, Korner H, Knyazev $P$, Diebold J, Hermeking $H$ : Inactivation of miR-34a by aberrant CpG methylation in multiple types of cancer. Cell Cycle 2008, 7:2591-2600

10. Leucci $E$, Cocco M, Onnis A, De Falco G, van Cleef $P$, Bellan C, van Rijk A, Nyagol J, Byakika B, Lazzi S, Tosi P, van Krieken H, Leoncini L: MYC translocation-negative classical Burkitt lymphoma cases: an alternative pathogenetic mechanism involving miRNA deregulation. J Pathol 2008, 216:440-450.

11. Toyota M, Suzuki H, Sasaki $Y$, Maruyama R, Imai $K$, Shinomura $Y$, Tokino $T$ : Epigenetic silencing of microRNA-34b/c and B-cell translocation gene 4 is associated with CpG island methylation in colorectal cancer. Cancer Res 2008, 68:4123-4132.

12. Suzuki H, Yamamoto E, Nojima M, Kai M, Yamano HO, Yoshikawa K, Kimura T, Kudo T, Harada E, Sugai T, Takamaru H, Niinuma T, Maruyama R, Yamamoto H, Tokino T, Imai K, Toyota M, Shinomura Y: Methylationassociated silencing of microRNA-34b/c in gastric cancer and its involvement in an epigenetic field defect. Carcinogenesis 2010, 31:2066-2073.

13. Vogt M, Munding J, Gruner M, Liffers ST, Verdoodt B, Hauk J, Steinstraesser L, Tannapfel A, Hermeking $H$ : Frequent concomitant inactivation of miR-34a and miR-34b/c by CpG methylation in colorectal, pancreatic, mammary, ovarian, urothelial, and renal cell carcinomas and soft tissue sarcomas. Virchows Arch 2011, 458:313-322.
14. Corney DC, Hwang Cl, Matoso A, Vogt M, Flesken-Nikitin A, Godwin AK, Kamat AA, Sood AK, Ellenson LH, Hermeking H, Nikitin AY: Frequent downregulation of miR-34 family in human ovarian cancers. Clin Cancer Res 2010, 16:1119-1128.

15. Kubo T, Toyooka S, Tsukuda K, Sakaguchi M, Fukazawa T, Soh J, Asano H, Ueno T, Muraoka T, Yamamoto H, Nasu Y, Kishimoto T, Pass HI, Matsui H, Huh NH, Miyoshi S: Epigenetic silencing of microRNA-34b/c plays an important role in the pathogenesis of malignant pleural mesothelioma. Clin Cancer Res 2011, 17:4965-4974.

16. Chakraborty C, George Priya Doss C, Bandyopadhyay S: miRNAs in insulin resistance and diabetes-associated pancreatic cancer: the 'minute and miracle' molecule moving as a monitor in the 'genomic galaxy'. Curr Drug Targets 2013, 14:1110-1117.

17. Chang TC, Wentzel EA, Kent OA, Ramachandran $\mathrm{K}$, Mullendore M, Lee KH, Feldmann G, Yamakuchi M, Ferlito M, Lowenstein CJ, Arking DE, Beer MA, Maitra A, Mendell JT: Transactivation of miR-34a by $\mathrm{p} 53$ broadly influences gene expression and promotes apoptosis. Mol Cell 2007, 26:745-752.

18. He L, He X, Lim LP, de Stanchina E, Xuan Z, Liang Y, Xue W, Zender L, Magnus J, Ridzon D, Jackson AL, Linsley PS, Chen C, Lowe SW, Cleary MA, Hannon GJ: A microRNA component of the p53 tumour suppressor network. Nature 2007, 447:1130-1134.

19. Raver-Shapira N, Marciano E, Meiri E, Spector Y, Rosenfeld N, Moskovits N, Bentwich Z, Oren M: Transcriptional activation of miR-34a contributes to p53-mediated apoptosis. Mol Cell 2007, 26:731-743.

20. Tarasov V, Jung P, Verdoodt B, Lodygin D, Epanchintsev A, Menssen A, Meister $G$, Hermeking $H$ : Differential regulation of microRNAs by $p 53$ revealed by massively parallel sequencing: miR-34a is a p53 target that induces apoptosis and G1-arrest. Cell Cycle 2007, 6:1586-1593.

21. Yan F, Liu H, Liu Z: Dynamic analysis of the combinatorial regulation involving transcription factors and microRNAs in cell fate decisions. Biochim Biophys Acta 1844, 2014:248-257.

22. Kaller M, Liffers ST, Oeljeklaus S, Kuhlmann K, Roh S, Hoffmann R, Warscheid B, Hermeking $\mathrm{H}$ : Genome-wide characterization of miR-34a induced changes in protein and mRNA expression by a combined pulsed SILAC and microarray analysis. Mol Cell Proteomics 2011, 10:M111 010462.

23. Welch C, Chen Y, Stallings RL: MicroRNA-34a functions as a potential tumor suppressor by inducing apoptosis in neuroblastoma cells. Oncogene 2007, 26:5017-5022.

24. Fujita Y, Kojima K, Hamada N, Ohhashi R, Akao Y, Nozawa Y, Deguchi T, Ito M: Effects of miR-34a on cell growth and chemoresistance in prostate cancer PC3 cells. Biochem Biophys Res Commun 2008, 377:114-119.

25. Yamakuchi M, Ferlito M, Lowenstein CJ: miR-34a repression of SIRT1 regulates apoptosis. Proc Natl Acad Sci U S A 2008, 105:13421-13426.

26. Li T, Kon N, Jiang L, Tan M, Ludwig T, Zhao Y, Baer R, Gu W: Tumor suppression in the absence of p53-mediated cell-cycle arrest, apoptosis, and senescence. Cell 2012, 149:1269-1283.

27. Valente LJ, Gray DH, Michalak EM, Pinon-Hofbauer J, Egle A, Scott CL, Janic A, Strasser A: p53 efficiently suppresses tumor development in the complete absence of its cell-cycle inhibitory and proapoptotic effectors p21, Puma, and Noxa. Cell Rep 2013, 3:1339-1345.

28. Lovis P, Roggli E, Laybutt DR, Gattesco S, Yang JY, Widmann C, Abderrahmani A, Regazzi R: Alterations in microRNA expression contribute to fatty acid-induced pancreatic beta-cell dysfunction. Diabetes 2008, 57:2728-2736.

29. Roggli E, Britan A, Gattesco S, Lin-Marq N, Abderrahmani A, Meda P, Regazzi R: Involvement of microRNAs in the cytotoxic effects exerted by proinflammatory cytokines on pancreatic beta-cells. Diabetes 2010, 59:978-986.

30. Yamakuchi M, Lowenstein CJ: MiR-34, SIRT1 and p53: the feedback loop. Cell Cycle 2009, 8:712-715.

31. Kawauchi K, Araki K, Tobiume K, Tanaka N: p53 regulates glucose metabolism through an IKK-NF-kappaB pathway and inhibits cell transformation. Nat Cell Biol 2008, 10:611-618.

32. Bensaad K, Tsuruta A, Selak MA, Vidal MN, Nakano K, Bartrons R, Gottlieb E, Vousden KH: TIGAR, a p53-inducible regulator of glycolysis and apoptosis. Cell 2006, 126:107-120.

33. Schwartzenberg-Bar-Yoseph F, Armoni M, Karnieli E: The tumor suppressor p53 down-regulates glucose transporters GLUT1 and GLUT4 gene expression. Cancer Res 2004, 64:2627-2633. 
34. Suzuki S, Tanaka T, Poyurovsky MV, Nagano H, Mayama T, Ohkubo S, Lokshin M, Hosokawa H, Nakayama T, Suzuki Y, Sugano S, Sato E, Nagao T, Yokote K, Tatsuno I, Prives C: Phosphate-activated glutaminase (GLS2), a p53-inducible regulator of glutamine metabolism and reactive oxygen species. Proc Natl Acad Sci U S A 2010, 107:7461-7466.

35. Matoba S, Kang JG, Patino WD, Wragg A, Boehm M, Gavrilova O, Hurley PJ, Bunz F, Hwang PM: p53 regulates mitochondrial respiration. Science 2006 312:1650-1653.

36. Jiang $P, D u$ W, Mancuso A, Wellen KE, Yang X: Reciprocal regulation of $\mathrm{p} 53$ and malic enzymes modulates metabolism and senescence. Nature 2013, 493:689-693.

37. Lagger G, Doetzlhofer A, Schuettengruber B, Haidweger E, Simboeck E Tischler J, Chiocca S, Suske G, Rotheneder H, Wintersberger E, Seiser C: The tumor suppressor p53 and histone deacetylase 1 are antagonistic regulators of the cyclin-dependent kinase inhibitor p21/WAF1/CIP1 gene. Mol Cell Biol 2003, 23:2669-2679.

38. Gronroos E, Terentiev AA, Punga T, Ericsson J: YY1 inhibits the activation of the p53 tumor suppressor in response to genotoxic stress. Proc Natl Acad Sci U S A 2004, 101:12165-12170.

39. Sui G, Affar el B, Shi Y, Brignone C, Wall NR, Yin P, Donohoe M, Luke MP, Calvo D, Grossman SR, Shi Y: Yin Yang 1 is a negative regulator of $\mathrm{p} 53$ Cell 2004, 117:859-872

40. Cole KA, Attiyeh EF, Mosse YP, Laquaglia MJ, Diskin SJ, Brodeur GM, Maris JM: A functional screen identifies miR-34a as a candidate neuroblastoma tumor suppressor gene. Mol Cancer Res 2008, 6:735-742.

41. Ji Q, Hao X, Meng Y, Zhang M, Desano J, Fan D, Xu L: Restoration of tumor suppressor miR-34 inhibits human p53-mutant gastric cancer tumorspheres. BMC Cancer 2008, 8:266.

42. Sun F, Fu H, Liu Q, Tie Y, Zhu J, Xing R, Sun Z, Zheng X: Downregulation of CCND1 and CDK6 by miR-34a induces cell cycle arrest. FEBS Lett 2008 , 582:1564-1568.

43. Migliore C, Petrelli A, Ghiso E, Corso S, Capparuccia L, Eramo A, Comoglio PM, Giordano S: MicroRNAs impair MET-mediated invasive growth. Cancer Res 2008, 68:10128-10136

44. Li WQ, Chen C, Xu MD, Guo J, Li YM, Xia QM, Liu HM, He J, Yu HY, Zhu L: The rno-miR-34 family is upregulated and targets ACSL1 in dimethylnitrosamine-induced hepatic fibrosis in rats. FEBS $\mathcal{J} 2011$, 278:1522-1532.

45. Shim H, Dolde C, Lewis BC, Wu CS, Dang G, Jungmann RA, Dalla-Favera R, Dang CV: c-Myc transactivation of LDH-A: implications for tumor metabolism and growth. Proc Natl Acad Sci U S A 1997, 94:6658-6663.

46. Miao P, Sheng S, Sun X, Liu J, Huang G: Lactate dehydrogenase a in cancer: A promising target for diagnosis and therapy. IUBMB Life 2013, 65:904-910

47. Le A, Cooper CR, Gouw AM, Dinavahi R, Maitra A, Deck LM, Royer RE, Vander Jagt DL, Semenza GL, Dang CV: Inhibition of lactate dehydrogenase $\mathrm{A}$ induces oxidative stress and inhibits tumo progression. Proc Natl Acad Sci U S A 2010, 107:2037-2042.

48. Fantin VR, St-Pierre J, Leder P: Attenuation of LDH-A expression uncovers a link between glycolysis, mitochondrial physiology, and tumor maintenance. Cancer Cell 2006, 9:425-434.

49. Dang CV, Le A, Gao P: MYC-induced cancer cell energy metabolism and therapeutic opportunities. Clin Cancer Res 2009, 15:6479-6483.

50. Cannell IG, Bushell M: Regulation of Myc by miR-34c: A mechanism to prevent genomic instability? Cell Cycle 2010, 9:2726-2730.

51. Dang CV, Kim JW, Gao P, Yustein J: The interplay between MYC and HIF in cancer. Nat Rev Cancer 2008, 8:51-56.

52. Semenza GL, Jiang BH, Leung SW, Passantino R, Concordet JP, Maire $P$, Giallongo A: Hypoxia response elements in the aldolase A, enolase 1, and lactate dehydrogenase $A$ gene promoters contain essential binding sites for hypoxia-inducible factor 1. J Biol Chem 1996, 271:32529-32537.

53. Firth JD, Ebert BL, Ratcliffe PJ: Hypoxic regulation of lactate dehydrogenase A. Interaction between hypoxia-inducible factor 1 and cAMP response elements. J Biol Chem 1995, 270:21021-21027.

54. Dang CV: The interplay between MYC and HIF in the Warburg effect. Ernst Schering Found Symp Proc 2007, 4:35-53.

55. Yang W, Zheng Y, Xia Y, Ji H, Chen X, Guo F, Lyssiotis CA, Aldape K, Cantley LC, LU Z: ERK1/2-dependent phosphorylation and nuclear translocation of PKM2 promotes the Warburg effect. Nat Cell Biol 2012, 14:1295-1304.

56. Gottfried E, Lang SA, Renner K, Bosserhoff A, Gronwald W, Rehli M, Einhell S, Gedig I, Singer K, Seilbeck A, Mackensen A, Grauer O, Hau P, Dettmer K,
Andreesen R, Oefner PJ, Kreutz M: New aspects of an old drug-diclofenac targets MYC and glucose metabolism in tumor cells. PLoS One 2013, 8:e66987.

57. Cui J, Shi M, Xie D, Wei D, Jia Z, Zheng S, Gao Y, Huang S, Xie K: FOXM1 Promotes the Warburg Effect and Pancreatic Cancer Progression via Transactivation of LDHA Expression. Clin Cancer Res 2014.

58. Tang Y, Zhao W, Chen Y, Zhao Y, Gu W: Acetylation is indispensable for p53 activation. Cell 2008, 133:612-626.

59. Rottiers $\mathrm{V}$, Naar AM: MicroRNAs in metabolism and metabolic disorders. Nat Rev Mol Cell Biol 2012, 13:239-250.

60. Kanno T, Sudo K, Maekawa M, Nishimura Y, Ukita M, Fukutake K: Lactate dehydrogenase $M$-subunit deficiency: a new type of hereditary exertional myopathy. Clin Chim Acta 1988, 173:89-98.

61. Knight JR, Milner J: SIRT1, metabolism and cancer. Curr Opin Oncol 2012, 24:68-75.

62. Mao B, Zhao G, Lv X, Chen HZ, Xue Z, Yang B, Liu DP, Liang CC: Sirt1 deacetylates c-Myc and promotes c-Myc/Max association. Int J Biochem Cell Biol 2011, 43:1573-1581.

63. Menssen A, Hydbring P, Kapelle K, Vervoorts J, Diebold J, Luscher B, Larsson LG, Hermeking H: The c-MYC oncoprotein, the NAMPT enzyme, the SIRT1-inhibitor DBC1, and the SIRT1 deacetylase form a positive feedback loop. Proc Natl Acad Sci U S A 2012, 109:E187-E196.

64. Saleh AD, Savage JE, Cao L, Soule BP, Ly D, DeGraff W, Harris CC, Mitchell JB, Simone NL: Cellular stress induced alterations in microRNA let-7a and let-7b expression are dependent on $\mathrm{p} 53$ PLoS One 2011, 6:e24429.

65. Lee JY, Kim HJ, Yoon NA, Lee WH, Min YJ, Ko BK, Lee BJ, Lee A, Cha HJ, Cho WJ, Park JW: Tumor suppressor p53 plays a key role in induction of both tristetraprolin and let-7 in human cancer cells. Nucleic Acids Res 2013, 41:5614-5625.

66. Zhu H, Shyh-Chang N, Segrè AV, Shinoda G, Shah SP, Einhorn WS, Takeuch A, Engreitz JM, Hagan JP, Kharas MG, Urbach A, Thornton JE, Triboulet R, Gregory RI, DIAGRAM Consortium; MAGIC Investigators, Altshuler D, Daley GQ: The Lin28/let-7 axis regulates glucose metabolism. Cell 2011, 147:81-94.

67. Thornton JE, Gregory RI: How does Lin28 let-7 control development and disease? Trends Cell Biol 2012, 22:474-482.

68. Bohlig $L$, Friedrich $M$, Engeland $K$ : $p 53$ activates the PANK1/miRNA-107 gene leading to downregulation of CDK6 and p130 cell cycle proteins. Nucleic Acids Res 2011, 39:440-453.

69. Yamakuchi M, Lotterman CD, Bao C, Hruban RH, Karim B, Mendell JT, Huso D. Lowenstein CJ: P53-induced microRNA-107 inhibits HIF-1 and tumor angiogenesis. Proc Natl Acad Sci U S A 2010, 107:6334-6339.

70. Lim JH, Lee YM, Chun YS, Chen J, Kim JE, Park JW: Sirtuin 1 modulates cellular responses to hypoxia by deacetylating hypoxia-inducible factor 1alpha. Mol Cell 2010, 38:864-878.

71. Chen R, Dioum EM, Hogg RT, Gerard RD, Garcia JA: Hypoxia increases sirtuin 1 expression in a hypoxia-inducible factor-dependent manner. J Biol Chem 2011, 286:13869-13878.

72. Eades G, Yao Y, Yang M, Zhang Y, Chumsri S, Zhou Q: miR-200a regulates SIRT1 expression and epithelial to mesenchymal transition (EMT)-like transformation in mammary epithelial cells. J Biol Chem 2011, 286:25992-26002.

73. Golshani-Hebroni SG, Bessman SP: Hexokinase binding to mitochondria: a basis for proliferative energy metabolism. J Bioenerg Biomembr 1997 29:331-338.

74. Granchi C, Bertini S, Macchia M, Minutolo F: Inhibitors of lactate dehydrogenase isoforms and their therapeutic potentials. Curr Med Chem 2010, 17:672-697.

75. DeBerardinis RJ, Thompson CB: Cellular metabolism and disease: what do metabolic outliers teach us? Cell 2012, 148:1132-1144.

76. Heltweg B, Gatbonton T, Schuler AD, Posakony J, Li H, Goehle S, Kollipara R, Depinho RA, GU Y, Simon JA, Bedalov A: Antitumor activity of a smallmolecule inhibitor of human silent information regulator 2 enzymes. Cancer Res 2006, 66:4368-4377.

77. Solomon JM, Pasupuleti R, Xu L, McDonagh T, Curtis R, DiStefano PS, Huber LJ: Inhibition of SIRT1 catalytic activity increases p53 acetylation but does not alter cell survival following DNA damage. Mol Cell Biol 2006, 26:28-38.

78. Brooks CL, Gu W: How does SIRT1 affect metabolism, senescence and cancer? Nat Rev Cancer 2009, 9:123-128. 
79. Kim JW, Gao P, Liu YC, Semenza GL, Dang CV: Hypoxia-inducible factor 1 and dysregulated c-Myc cooperatively induce vascular endothelial growth factor and metabolic switches hexokinase 2 and pyruvate dehydrogenase kinase 1. Mol Cell Biol 2007, 27:7381-7393.

80. Osthus RC, Shim H, Kim S, Li Q, Reddy R, Mukherjee M, Xu Y, Wonsey D, Lee LA, Dang CV: Deregulation of glucose transporter 1 and glycolytic gene expression by c-Myc. J Biol Chem 2000, 275:21797-21800.

doi:10.1186/1476-4598-13-115

Cite this article as: Zhang et al:: P53/microRNA-34-induced metabolic regulation: new opportunities in anticancer therapy. Molecular Cancer 2014 13:115

\section{Submit your next manuscript to BioMed Central and take full advantage of:}

- Convenient online submission

- Thorough peer review

- No space constraints or color figure charges

- Immediate publication on acceptance

- Inclusion in PubMed, CAS, Scopus and Google Scholar

- Research which is freely available for redistribution 